\title{
Managing Schools in Brussels: Selection and Local Interdependencies
}

\section{Perrine Devleeshouwer}

Université de Cergy-Pontoise (France)

doi: 10.7358/ecps-2015-011-devl

pedevlee@ulb.ac.be

\section{GESTIRE SCUOLE A BRUXELLES: LA SELEZIONE \\ E LE INTERDIPENDENZE LOCALI}

\section{Abstract}

This paper underlines selection processes in the Belgian educational school system. It analyses the schools' reactions to the recent modification of the enrolment policy that diminishes the freedom that schools have historically benefitted from to regulate their population. The paper shows that the management variations between schools have to be understood with regard to the local interdependencies between them. These local interdependencies constitute hierarchies that form a frame for individual actions in school which contribute to reproduce the hierarchical structure. Doing so, it insists on the necessity to understand the quasi-market and the competition between schools by taking in account the local social and demographic context. School managing practices are not only due to a mechanical cause-effect link with their position in the educational hierarchies. This paper shows that, when studying the actors' perception in detail, the hierarchies constitute a frame for their actions at a more local level. In this sense, the weight of hierarchies and interdependencies is not automatically built on the spaces defined by flow of pupils between schools. Theses spaces are not a fixed frame for educational actions even within schools sharing a similar position in the hierarchies.

Keywords: Brussels, Education, Hierarchies, Local interdependencies, Schools.

\section{INTRODUCTION}

This paper sheds light on school management practices in a school system organised as a poorly regulated quasi-market. In most Western countries, 
the democratisation of education and the development of mass education have led, on the one hand, to differentiation, hierarchies and segregation of school systems and, on the other, to a transformation of school regulations (Draelants \& Dumay, 2011). This transformation corresponds to a standardisation of the goals of the school systems, but also to more freedom given to local authorities. However, in Belgium the decentralisation towards local authorities is a historical reality as it was established in the Constitution as early as 1831. In Belgium as in other countries, schools are differentiated and segregated. The present tendency is to regulate more the educational quasimarket in order to diminish the weight segregation plays on performances. Indeed, since 2007, the enrolment procedure for the first year of secondary education has been centralised. One of the main aims of this new regulation is to create more social mix in schools.

This paper explores the schools' reaction to this regulation. Before these regulations, the selection of the school population was one of the main tools to manage their image and reputation in order to maintain or change their position in the educational hierarchies due to the quasi-market. We expect they will find other management practices to maintain their hierarchical position. Before describing our methodology and our results, we first have to more theoretically outline the dynamics of schools management practices in the context of mass education and of decentralised quasi-market.

\section{SCHOOLS UNDER PRESSURE?}

Decentralised modes of regulation leave relative freedom to local authorities and to schools to organise their educational offer, their pedagogy and to manage the school population. In Belgium this freedom has existed historically. Schools are able to create their own specifications according to the characteristics of their local environment, of the perceptions educational actors have of their own role, and as a function of their population (Draelants \& Dumay, 2011). There is too little coordination between local authorities and schools. This does not allow for an effective regulation of the school system and leads to segregation by "letting the market have its own way» (Felouzis, Liot, \& Perroton, 2005, p. 209). In decentralised school systems, the debates about the role of education and its regulation are up to the schools themselves. It makes them the essential place of strategic actions for families, pupils, educational teams and political regulation (Draelants \& Dumay, 2011)

Hence, it is interesting to look at the forms of the schools' strategic actions. They come from a dynamic reaction to their local environment 
(Van Zanten, 2000) which is mainly made up of the school users and of other locally implemented schools. In other words, families and other schools exert pressure on a school, and the latter reacts to the pressures by trying to reduce them or to move them to another school. In concrete terms, educational workers develop activities that aim to retain the best pupils. However, the amount of actions that schools need to fulfil this aim depends on their own characteristics and resources which vary according to their position in the educational hierarchies (Van Zanten, 2000). Where hierarchy and market are an integral part of school systems, some schools have more margins for developing their actions whereas some other schools are more under competitive pressure. This hierarchy between schools constitutes an internalized framework shared by all educational actors as an obvious fact: what has been called an instituted hierarchy (Delvaux, 1999). It means that the hierarchy is not built on objective criteria about the quality of teaching, but rather on reputations and social representations spread by social networks (Maroy, 2004).

In this context, schools having more demands than offers have the possibility to choose their pupils and this contributes to reinforce the unequal division of populations and educational segregation. The competition to attract pupils should force schools to aim at more efficiency in order to improve their reputation, but Maroy (2004) shows the reverse: schools are embedded in a complementary differentiation - a kind of specialisation of their profile. On the one hand, some schools are specialised in receiving pupils that other schools do not want. They receive pupils that cannot enrol in other schools because of orientations, repetitions or expulsions. On the other hand, some other schools can keep pupils that are perceived as conforming to the educational norms of excellence. This complementary differentiation creates a two-tier system, a social and ethnic educational apartheid.

Understanding these logics of competition has to be done on a local scale (Ball, Bowe, \& Gerwitz, 1997; Noden, 2000). The multiple links between school regulation, urban segregation and the families' strategies (Felouzis et al., 2005) have been captured by different concepts. For example, Ball, Bowe and Gerwitz (1997) use the term circuit. It designates the configurations of the schools' catchment areas and neighbourhood in which different categories of pupils move (François \& Poupeau, 2008). The circuit varies according to the position of the school and to the social profile of its population. The concept of competition spaces (Broccolichi \& Van Zanten, 1997) underlines the same kind of dynamics. It insists on the historical, economic and demographic factors influencing local spaces of school choices. In Belgium, the concept of local interdependencies has been put forward (Delvaux, 2005 and 2006; Delvaux \& Joseph, 2006; Delvaux \& Van Zanten, 2006). It shows the weight of the geography of pupil flows on the structure of local spaces 
that will be a framework for the actions of schools and families. These three concepts underline the families' strategies depending on social classes, cultural capital and choices in local spaces (Delvaux \& Joseph, 2006). The three concepts also capture - and this is what interests us - the schools' strategies. They show that schools' strategies depend on their position in locally built hierarchies. The hierarchies are revealed by the asymmetrical flows of pupils between schools: some schools receive more pupils than they expel while others receive fewer pupils than they expel (Delvaux \& Joseph, 2006). The former schools occupy a better position in the educational hierarchy than do the latter. Moreover, there is a link between the position the school occupies in the hierarchy and some of its characteristics. In Belgium, schools that are privileged in the hierarchies are in the general tracks and rarely offer vocational training; they receive more enrolment applications than the vacancies available, they have better academic results (measured by numbers of reorientations and repeated years) and their population is more privileged, socioeconomically speaking. On the other hand, schools at the bottom end of the hierarchies have fewer applications to enrol than vacancies available, weak academic results, offer vocational training and have a poor population (Delvaux \& Joseph, 2006).

The possibility to develop strategic actions varies according to the schools' position in this hierarchy. The lower rank schools aim to keep a sufficient number of pupils to maintain their existence. They cannot afford to try changing their population's profile as they have to accept every pupil wanting to enrol. The more privileged schools are exempted from the market effect thanks to their high number of entry applications. In this sense, they do not have to modify their strategy to maintain their position (Thrupp, 2007). However, the schools' strategies do not only consist of trying to attract the maximum number of pupils. It is also a matter of the kind of pupils to have. Indeed, schools at the top end of the educational hierarchies manage to attract the valorised pupils: youths that are perceived as the best academically and the easiest to teach. What is interesting is that the competition for these pupils mainly occurs between schools sharing a similar position in the hierarchies (Delvaux \& Jospeh, 2006).

Studies on school strategies can lead to a dichotomist perception of school practices. Indeed, they tend to focus on both ends of the educational ladder: on the one hand, elite schools having the possibility to select pupils within a privileged population with few foreign backgrounds while, on the other, ghettoized schools having to accept every pupil knocking at their doors with an underprivileged population and a high rate of pupils with foreign backgrounds. It seems that schools in between these two extremes are poorly studied even if they present various profiles (Delvaux \& Joseph, 2006). Hence, 
in order to bring a new insight to the analysis of schools' strategies and management practices, we studied schools with an intermediary position in the educational hierarchies: neither elite schools nor ghetto schools. We call them average schools. By studying their reactions to - and the practices they developed after - the new regulations of the enrolment policies in French-speaking Belgium, we would like to see if these schools only present profiles that could be close to either the elite schools or to the ghetto schools, or whether, on the contrary, the analysis leads us to find a new kind of school practice.

\section{Methodology}

In order to select the average schools, we employed a purposive sampling procedure using the two main forms of hierarchy as criteria: (1) educational tracks, (2) the socioeconomic level of school populations (Devleeshouwer \& Rea, 2011). With regard to educational track, we chose schools from the general teaching track since - in French-speaking Belgium - vocational tracks are in the lower end of educational hierarchies. As regards the socioeconomic profile, we selected schools which are close to the average population of Brussels having at least a secondary education degree from the general track ${ }^{1}$. Combining these criteria, we selected 5 schools in order to have an in-depth analysis of their practices. They should, therefore, not be considered as a representative sample of the schools in Brussels.

In these schools, we collected the data in the last year of secondary education in order to retrace the pupils' educational careers. We used both quantitative and qualitative data in the study. The quantitative data are based on questionnaires filled in by pupils from the last year of secondary education in the 5 selected schools ${ }^{2}$. In this paper, the quantitative data are only used to describe the general characteristics of each schools. The analysis relies on the qualitative data. They are based on semi-structured interviews with 40 pupils from the last year of secondary education and 27 members from educational teams. The interviews aim to talk freely about educational perceptions and careers of pupils and teachers in order to reveal the actors' own mode of categorisation. They are analysed by content-analysis.

Before detailing the schools practices, it is interesting to look at their general characteristics to better understand what average schools are. The

1 In Brussels, $61.9 \%$ of the population has at least a degree from the general track (Atlas de la Santé et du Social de Bruxelles-Capitale, 2006, p. 88).

$2 \mathrm{Nr} .=160$, Response rate $86.5 \%$. 
sample is more disadvantaged and ethnically more diverse than the population of Brussels. The latter population is slightly more educated than the sample. The sample has an under-representation of employees and an overrepresentation of non-working population (especially for women). Youth with a foreign background (two parents born abroad) are also over-represented in our sample and the two main origins are Morocco and Turkey. Pupils of the sample mainly live in relatively disadvantaged areas: Molenbeek $(30 \%)$ and Schaerbeek (21\%). Hence, academically speaking, the sample is quite privileged. They occupy a good ranking position (they are in general teaching), the rate of non-repeaters is close to the average of French-speaking Belgium.

\section{MANAGING AVERAGE SCHOOLS: THREE IDEAL-TYPES}

We started our analysis by conducting monographs of each investigated school. The aim of this work was to describe in detail the way educational actors perceive their schools and the practices they develop. On the basis of these monographs, we looked at their common traits and at what could differentiate them. Doing so, we opted for an inductive approach that leaves the concepts emerging from the actors' own modes of categorisation. The analysis shows that we can differentiate average schools on the basis of two dimensions. These dimensions give three ideal-types of average schools. However, we shall also see that three ideal-types share some similarities. Before shedding light on these similarities, let us first present the three types of average schools emerging from our results.

Two dimensions allow us to differentiate them. The first dimension concerns the divergence or the uniformity of the discourses in one school. In some schools, the discourses are divergent and different perceptions of the schools emerge, whereas in other schools, the discourses are more uniform as they tend to focus on the same kind of perception of the school. The second dimension concerns the content of the discourses. It appears that the perceptions about the role that the school should play in society is given a great importance in the discourses, sometimes more than actual pedagogical practices. Let us note that Beaud (1996) already underlined that teachers tend to feebly speak about the practical aspects of their work in sociological interviews because they see it as a discussion between intellectuals. More precisely, in our interviews, the practical aspects of working in schools were spontaneously brought forward by interviewees, but always explained by the meaning they should have and by the purpose they should serve. 


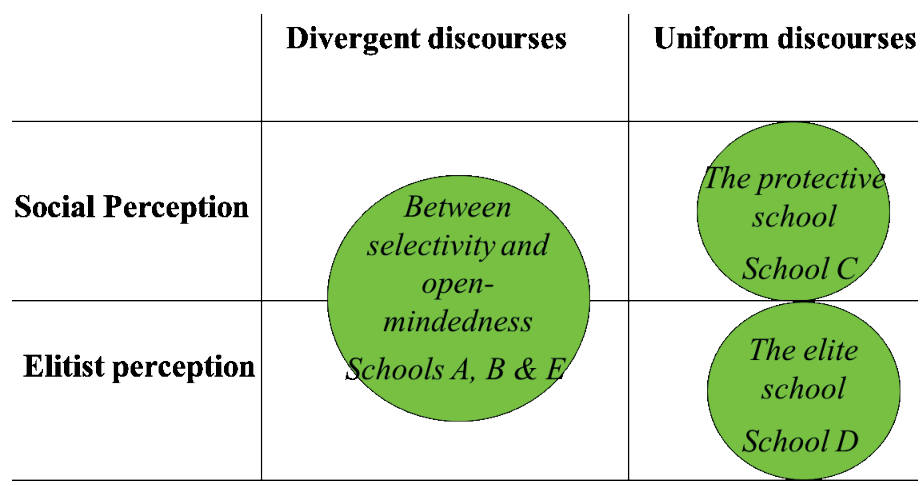

Figure 1. - Three ideal-types of average schools.

The second dimension opposes what we call a social perception of the role of school and an elitist perception of the role of school. As Figure 1 shows, with these two dimensions, three types of average schools emerge: the protective school, the elite school and the school between selectivity and open-mindedness.

The protective and the elite schools are close to what is usually described with regard to the two top-ends of educational hierarchies. The school between selectivity and open-mindedness gives a more complex picture to grasp.

\subsection{The protective school}

Looking at objective descriptive variables, the protective school is close to the figure generally given to ghetto schools. It is situated in a socio-economically disadvantaged neighbourhood and has a very locally based catchment area. Its population has the most academic difficulties (measured by the mean of repeated years) in comparison to the other schools, but it is not necessarily the most disadvantaged of the 5 investigated schools. It means that the school is perceived as having to help to develop the pupils' social emancipation and to provide them with individual help to face their academic difficulties. Here, there is what we could call a strongly shared militant perception of the school. The protective school is seen as a place that protects youths from the urban environment as this is considered dangerous. The school is also seen as a place that protects and reconstructs the educational positive identities of its pupils. 
The small size of the school is a positive aspect of it. We often say that we have a familial atmosphere. It means that teachers know the pupils. The groups are not big, the classes I mean, are not big - thank God - so we are attentive to each pupil. Pupils also know the teachers and I know the pupils and so on. I mean that when we see pupils outside the school in the street, we say hello to each other. Another thing is that parents know that we look after their children. We react as soon as there are some drop-outs or pupils not attending. The neighbourhood is quite difficult, it has to be said. But despite that, I have the feeling that pupils, parents and teachers think this school is a place of serenity not like the neighbourhood. So it is nice in this way. There are no acts of violence in our school. But that is also because we have to expel the troublemakers. This does not happen often - we had 3 or 4 expulsions this year - but it is always a case of failure for us to have to dismiss a pupil. (Head teacher)

Here, I have never seen a teacher saying «No, I am busy» if you want to ask something after the lesson, never! Because, I know I have difficulties. Actually, if I want to understand well, I must exercise a lot and that I show my results to the teacher. If I don't, I will not understand and this has to be done outside the lesson hours. So, if the teachers do not teach outside school hours, I am lost. This is why I stay in this school. (Boy, first generation, Congolese origin, 0 repeated years, 0 changes of school)

Most discourses link the familiar aspect of the school with its small size that enables pedagogical practices of support. The school's image is not built by an association between the characteristics of the nearby urban environment, but rather by an opposition to the perceived dynamics of the neighbourhood and of the school system as a whole. In the protective school, the relegated position in the educational hierarchies is positively claimed because it gives a meaning to the work of teachers and to the educational experience of pupils.

This strong orientation of the discourses is attributed by the interviewee to the personality of the head teacher who insists on collective and collaborative work between teachers as well as the taking into account of pupils' possible difficulties (academic ones and personal ones). Teachers also insist on the solidarity existing in their team as well as on the efforts they make in order to integrate newcomers.

Through this work, they think that the school manages to gain a good reputation in the neighbourhood and does not constitute a second choice school for pupils. Indeed, according to pupils, the school has a good reputation. This is evaluated by comparing with other schools of the neighbourhood.

How to put it? There is no rascal. Well, I don't really know if I should say it like that. In other schools of the neighbourhood, there are youths that fuck shit up. They do rubbish, but in this school pupils are quieter and teachers as well. (Boy, second generation, Moroccan origin, 1 repeated year, 0 changes of schools) 
The protective school is not a ghetto school in the sense Baillon (1986) gives to this notion. Indeed, according to Baillon, the ghetto schools are strongly refused by families. However, in the protective school we can find some perceptions that have been shown elsewhere to be linked with the relation of middle class to education: the importance of wellbeing at school and of the individual support given to pupils, as well as some fears about safety (Van Zanten, 2009).

\subsection{The elite school}

The elite school is, to a certain extent, the opposite of the protective school. It is situated in a slightly more socially privileged area and its population is also more privileged than in the protective school. Pupils have more linear educational careers, but are not, however, the most privileged of our sample, academically speaking. The recruitment area is larger than the protective schools' one, but it is not the largest of the sample.

As in the protective school, discourses in the elite school are relatively uniform, but emphasize an elite perception of the role of education and of the school. They insist on school norms, on pupils performances, on meritocracy, and on the necessity to help pupils succeed in higher education. In this perception, the selection of the school's population is seen as a necessity that helps to maintain the good academic level of the school as well as its good reputation.

Before the new registration policy, we were trying to enrol pupils that had, of course, their CEB [the primary education degree], but also pupils that had a good level; but with the new policy we cannot do anything like this anymore. So, it is a little bit of a problem because we have to admit everyone. We have classes in the first year of secondary education that are really big and then in the following years it is like a pyramid. There is a selection being made. It is inevitable. Also, it is because the school tries to keep its level and its demanding nature. If we accept more pupils in the beginning who are weaker, it is sure that we have to select. Teachers working with first year secondary education students - and they do a really good job - have difficulties in assessing the pupils and in keeping discipline. In the following years we have less disciplinary problems because the selection has already been done. In the third year the academic level is really not good. (French teacher)

The discourses underline the average status of the school in the educational hierarchies. The definition given to the average school, here, is managing to maintain a good academic level despite the low social profile of the pupils. This is carried out through the disciplinary norms, but also through the creation of a good atmosphere. 
The atmosphere is happy despite being a bit messy! I think the environment is more or less good even if pupils are not always easy - well they are not very difficult either. It is a good average, not average performance, but a good average of behaviour. We have problems, as everywhere. So it is neither a bad school nor a good school, it is an average school, a local school. With the difficulties we have, we do well. If we look at pupils' results, I think we manage to arrive, at the end of secondary education, to have pupils that can do something in higher education. (Reatho-Romanic teacher)

In other words, the school is seen as a local school and that explains, for the teachers, the pupils' social characteristics. However, teachers insist on the fact their school is better than the other schools of the neighbourhood. This perception also appears in the way pupils have chosen the school: they mix proximity, the options offered and the reputation about the academic level and the pedagogical project of the school.

My parents have chosen this school because it is near our house. But there are other schools nearer. I think they wanted to have a school with a good level. So they have chosen this school after several researches, they said it has a good level - which is not untrue. (Boy, second generation, Moroccan origin, 1 repeated year, 0 changes of school)

As in the protective school, the uniformity of the discourses is attributed by the actors to the management style of the head teachers. S/he gives many indications to her/his educational team.

I think, in a school, a lot depends on the head teacher. Here, we have one that likes keeping things straight. A few years ago, he could have made the school part of the affirmation action program, but he didn't do it to maintain the good image and reputation of our school. It could have had negative consequences for us. More, he asks the teachers to prepare the kids for higher education. (German language teacher)

The discourses in the elite school strongly refer to a meritocratic and hierarchic perception of the society linked with an instrumental conception of education. It is oriented toward efficiency and effectiveness, but also toward the accumulation of knowledge and to the importance of educational hierarchies (Van Zanten, 2009). However, the elite school here is not a flagship school (Baillon, 1986). The flagship schools, according to Baillon, are strongly in demand and have a population of mainly socially privileged. They are schools that are not accessible to the majority of families. The elite school in our typology, even if its discourses are oriented toward meritocracy, is not a flagship school in Brussels' whole educational quasi-market. Indeed, pupils underline the average status of their school and valorise it. 
To me, the school is average in comparison to what I saw elsewhere. There is worse even in the general track. In the general track the school is higher than the average level, I would say. I have done some research and the school is one of the passable schools in Brussels, it is not the best. For example, I went one day to a school with a very high level, but it was very much every man for himself. The mentality of the people was weird: they look at you weirdly. They directly see that you are not from their school, so you are set apart. (Boy, first generation, Moroccan origin, 0 repeated years, 0 changes of schools)

\subsection{The school between selectivity and open-mindedness}

The image of this school is more difficult to grasp at a glance, and this is for its general characteristics as well as for the actors' discourses. Indeed, it can be situated in different kinds of neighbourhoods: socially mixed or disadvantaged. Its catchment area can be really localised or spread all over the city. Its population is close to the mean socioeconomic level of our sample. The perceptions about the role of the school fluctuate between the elitist and the social perception of education. These variations appear between different people, but also within the discourse of a single actor. The school is characterised by a search for balance between a social and a disciplinary orientation. The social orientation mainly refers here to the will of integrating the disadvantaged population in society through education. This can have consequences on teacher-pupil relations.

Social work with pupils creates bonds. Sometimes, it creates relations that should not exist between a young person and a teacher in the sense that we - as teachers - invest too much on social dimensions and not enough on academic dimensions. We diminish our pedagogical demands because we think a kid has big social problems, but sometimes the kid doesn't need that. In my view, some of my colleagues are too much "social workers» and only teachers after that. Some other colleagues really do not care. They teach and that is that. If someone does not understand, it is not their problem. I think we have to find a fair balance. The majority of us manage to find it. But, besides, you always find the extremes of too much social work or no social work at all. Both have limits. (Head teacher)

In parallel, this school develops many practices aiming at maintaining its position in the educational hierarchies - a position that is seen as average. These practices mainly consist of selection practices. Pupils who attend school for several years are the ones that have accepted the rules. Here, teachers mainly put forward behavioural rules: pupils not respecting them are oriented toward vocational tracks (in the same school or in another one). 
With the new regulation, we cannot refuse to admit anyone. We can try to reorient the kid, but not refuse the application. Any child in the age of mandatory education must be accepted. But now, it is clear that we look more for some profile of pupils, but it is not as a function of their foreign background. What matters is their behaviour. We manage to do it. We are not an elite school, but still we have a good academic level and we would like our pupils to succeed in their future lives. (Head teacher)

Unlike what constitutes the two other types of schools, here the discourses are varied and teachers insist on the different pedagogical practices they have.

The most difficult thing in this school is not the pupils, but the colleagues. Teaching is a very individual work. We are always alone; we do what we want in our class. So, I have some very lax colleagues: they come to the class, it is a mess, pupils draw on their table, and nobody works. Other colleagues are very strict. Also, there is no homogeneity in the aims. It means that some colleagues look for productivity: pupils must work hard, write a lot, and hand in essays. Other colleagues insist on oral expression. In a word, there is no coherence in our pedagogical team. I think it is because nothing is done by the head teacher, there is no management orientation at all. (History teacher)

\section{CONCLUSiON}

The ideal-types allow us to understand how average schools react to their position in the educational hierarchies. Before the change in the rules concerning the admission policy for secondary education, they used to select the pupils to admit. Now, they tend to postpone this selection to the following years. They perceive the new regulations as a difficulty to manage and to maintain their hierarchical position. In most actors' eyes, the selection of pupils is the only way to do so. Selection processes constitute the common feature of the average school. Indeed, it is a practice in the elite school as well as in schools which opt for selectivity and open-mindedness. In the protective school, selection is not valorised, but it is sometimes seen as a necessity to dismiss trouble makers. The insistence on selection processes reveals what makes the main feature of the average school: a tension between a school population generally perceived as underprivileged and the academic level conceived as relatively good or, at least, as average in comparison to other schools in the quasi-market. As elsewhere, the population of a school is a fundamental key of the image the families, the pupils and the teachers have of it (Felouzis et al., 2005). The pupils' social and ethnic diversity is perceived by teachers as a difficulty for their teaching work, but it is essential for 
all of them to try to overcome this difficulty. This can be done by emphasizing the social dimension (creating a good atmosphere, taking into account pupils' social problems, helping them to integrate in society) or by improving the meritocratic dimension (managing to have good performances despite the socially disadvantaged background). In order to maintain their performances and their standard, schools need to develop their selection criteria.

The average schools have a number of entry applications which is close to the one of resort schools described by Baillon (1986): these schools are chosen, on the one hand, by families refusing ghetto schools, but that cannot afford the flagship schools; but, on the other hand, the resort schools are refused by other families, who judge them not good enough for their children.

But these general qualities of the average positioned schools in the quasi-market hide some important differences in their pedagogical projects and in the concrete reactions to their practices. The concepts of circuits, competition spaces or local interdependences allow us, to a certain extent, to understand the three types of average schools we have put forward when they all had the same position in the hierarchies. Indeed, it is essential to take the sociospatial configurations into account when studying schools. They mainly react to their direct local environment and according to what they perceive of the local educational hierarchies even if, in some cases, they compare their situation to the entire city. This is interesting because according to the Belgian concept of local interdependencies, the local hierarchies are mainly built on pupil flows between schools. Following this approach, Brussels constitutes one single space of interdependencies. Despite the great number of pupils in the city, the sub-spaces in the urban area are not adequately independent from the rest of the urban space to speak of a proper space of local interdependencies (Delvaux, Guisset, \& Marissal, 2008). However, this paper shows that, when studying the actors' perception in detail, the hierarchies constitute a framework for their actions at a more local level. In this sense, the weight of hierarchies and interdependencies is not automatically built on the spaces defined by the flow of pupils between schools. Theses spaces are not a fixed framework for educational actions even within schools sharing a similar position in the hierarchies.

Another important aspect of our work is to underline the key role that head teachers play in school management practices. Indeed, when the head teacher adopts a strong management and strongly insists on certain perceptions of education or on collective work, the discourses are more homogenous than when this kind of management is not perceived by the educational teams. However, the management style does not influence the perception of the role of the schools and the direction given to the pedagogical project. At this point 
of our work, it seems that the development or not of a strong management style seems more linked with the personal character of the head teacher than to any other dimension of the school hierarchies or characteristics. It would be interesting to analyse this intuition further. Indeed, it raises interesting questions in terms of how head teachers are trained and on what their careers are.

\section{REFERENCES}

Baillon, R. (1986). Le choix du collège: le comportement «éclairé» des familles. Revue Française de Sociologie, 27(4), 719-734.

Ball, S. J., Bowe, R., \& Gerwitz, S. (1997). Circuits of schooling: A sociological exploration of parental choice of school in social-class contexts. In A. H. Halsey, H. Lauder, P. Brown, \& A. S. Wells (Eds.), Education. Culture, economy and society (pp. 409-421). New York: Oxford University Press.

Beaud, S. (1996). L'usage de l'entretien en sciences sociales. Plaidoyer pour l'entretien ethnographique. Politix, 9(35), 226-257.

Broccolichi, S., \& Van Zanten, A. (1997). Espaces de concurrence et circuits de scolarisation. L'évitement des collèges publics d'un district de la banlieue parisienne. Annales de la Recherche Urbaine, 75, 5-17.

Delvaux, B. (1999). Négocier la diversité: une utopie? In D. Meuret (Ed.), La justice du système éducatif (pp. 155-171). Bruxelles: De Boeck.

Delvaux, B. (2005). Régulation des interdépendances entre écoles: vers un modèle de la responsabilité collective? Recherches Sociologiques, 1, 29-51.

Delvaux, B. (2006). Compétition entre écoles et ségrégation des élèves dans six espaces locaux européens. Revue Française de Pédagogie, 156, Juillet-AoûtSeptembre, 63-73.

Delvaux, B., Guisset, C., \& Marissal, P. (2008). L'enseignement ancré dans des relations territorialisées: le projet des bassins scolaires. Territoire(s) Wallon(s), 2, 59-70.

Delvaux, B., \& Joseph, M. (2006). Hiérarchie et compétition entre écoles: le cas d'un espace local belge. Revue Française de Pédagogie, 156, Juillet-Août-Septembre, 19-27.

Delvaux, B., \& Van Zanten, A. (2006). Analyser les espaces locaux d'interdépendance: une clé pour comprendre ce que sont et produisent les établissements scolaires. Revue Française de Pédagogie, 156, Juillet-Août-Septembre, 5-8.

Devleeshouwer, P., \& Rea, A. (2011). Justification des différenciations scolaires par les acteurs de l'enseignement. Education Comparée. Revue de Recherche Internationale et Comparative en Éducation, 6, 161-180.

Draelants, H., \& Dumay, X. (2011). Lidentité des établissements scolaires. Paris: PUF. 
Felouzis, G., Liot, F., \& Perroton, J. (2005). L'appartheid scolaire. Paris: Seuil.

François, J. C., \& Poupeau, F. (2008). Les déterminants socio-spatiaux du placement scolaire. Essai de modélisation statistique appliquée aux collèges parisiens. Revue Française de Sociologie, 49(1), 93-126.

Maroy, C. (2004). L'impact du décret «Missions» sur les modes de régulation du système d'enseignement: discours et évolutions effectives. In M. Frenay \& C. Maroy (Eds.), L'école, 6 ans après le décret "Missions». Regards interdisciplinaires sur les politiques scolaires en Communauté française de Belgique. Louvainla-Neuve: Presses Universitaires de Louvain.

Noden, P. (2000). Rediscovering the impact of marketisation: Dimension of social segregation in England's secondary schools. British Journal of Sociology of Education, 2(3), 371-390.

Thrupp, M. (2007). Scholl admissions and the segregation of school intakes in New Zealand cities. Urban Studies, 44(7), 1393-1404.

Van Zanten, A. (2000). Massification et régulation du système d'enseignement. Adaptations et ajustements en milieu urbain défavorisé. L'Année Sociologique, 50(2), 409-436.

Van Zanten, A. (2009). Choisir son école. Paris: PUF.

\section{RiassunTO}

Questo articolo analizza le reazioni delle scuole alla recente modifica della politica delle iscrizioni che diminuisce la libertà di cui le stesse hanno storicamente beneficiato nel regolare la propria utenza. Il lavoro mostra come le differenze nella gestione delle scuole devono essere comprese in funzione delle interconnessioni che sussistono nel luogo. Queste interdipendenze locali costituiscono gerarchie che formano una cornice per le azioni individuali della scuola, la quale contribuisce cosi a riprodurre la struttura gerarchica stessa. Di conseguenza, si insiste sulla necessità di capire la situazione che viene a crearsi, simile a quella di un mercato, e la concorrenza tra le scuole, tenendo in considerazione il contesto sociale e demografico locale. Le professioni con compiti di gestione della scuola non sono da porre meccanicamente in un rapporto di causa-effetto con la posizione che esse occupano nelle gerarchie del sistema educativo. Questo articolo mostra che, quando si studia in dettaglio cio che viene percepito da chi agisce nel sistema scolastico, si osserva come le gerarchie costituiscano una struttura, per le loro azioni, molto legata alla dimensione locale. In questo senso il peso delle gerarchie e delle interdipendenze non è costruito automaticamente in base al flusso di alunni tra scuole. Tali spazi non sono un telaio fisso per le azioni formative anche all'interno delle scuole che condividono una posizione simile nelle gerarchie.

Parole chiave: Bruxelles, Educazione, Gerarchie, Interdipendenze locali, Scuole. 